Vitaliy Omelyanenko, Candidate of Economic Sciences, Senior Researcher, Sumy State Pedagogical University named after A. S. Makarenko (Sumy, Ukraine)

\title{
ANALYSIS OF INFORMATION ASYMMETRY IN INNOVATION SYSTEM SECURITY ENSURING
}

\begin{abstract}
The article deals with the main aspects of the role of information in innovation system development. The author proposes to consider the role of information in the context of innovation security and resource security of innovation system. The main forms of information asymmetry and its consequences for the various innovation agents were identified. The analysis of information asymmetry innovative security is proposed to be considered in the mutual dependence of innovation system parameters and degree of its stability, which can be achieved through information provision. Based on world experience the measures of information asymmetry reducing were proposed.

Keywords: innovation system, innovation security, information asymmetry, strategy, technology transfer, market.

DOI: 10.21272/mmi.2017.4-17
\end{abstract}

Introduction. Developed countries consider providing innovation security as one of state policy priorities. Also the experience of successful innovation based economies proves, that effective innovative systems formation, lasts about 20-25 years, that's why developing countries has emergently investigate the innovative strategy, the base of which is to be effective resource support system, which considers innovation and intellectual property traditional institutes. Taking into account necessity to use the existing technological potential and to define technologies import spheres, it is urgent to investigate informational aspect of resource support of international innovation integration. In the ideal market case uncertainty is entirely absent, which allows to use of existing facilities and resources in the most efficient way. However, in real life, the general rule deals with the lack of market information and its inaccessibility, which prevent the adoption of optimal solutions.

These aspects are greatly enhanced in innovation system and its resource provision, since it is characterized by complex resource relationships, in particular the added value chains at national and international levels. Another problem deals with the unequal distribution of available information among different market participants and economic agents, resulting in possible serious deformation behavior of partners, mediators, buyers and sellers.

In this regard, it is necessary to analyze the effect of incompleteness and asymmetry of information on decision-making and market operation of innovation system. But despite the long history of study of functioning of markets problems and successes, many of the problems associated with the emergence of distortions generated by the asymmetry and incomplete information, it is still not resolved.

Analysis of recent researches and publications has shown that the information factor is increasingly considered as factor of national security and its components (economic, information etc.) as well as innovation system development. But we also can notice, that the informational asymmetry in innovation area problem is not studied enough detail, because of the existence of differences in national innovation systems and innovation markets.

The problems of innovations development owing to high operational expenses and informational asymmetry in innovative sphere were studied by Arora A., Gans J. S., Stern S. [4]. Some authors point out that incompleteness of the patent market prevent from even attractive patents licensing.

Great contribution into the research of the information impact on market functioning was made by G. Akerlof, S. Grossman, F. Knight, M. Spence, J. Stiglitz, F. Hayek, D. Hicks, K. Arrow etc. Also authors have suggested ideas, that of institutes worsen selecting mechanisms functioning under conditions of 
transformation leads to informational flows asymmetry and to attempts of the proper groups to keep institutes with regressive return [1].

Paradox, that deals with information asymmetry, was firstly described in 1970 by Nobel laureate G. Akerlof in his research "Market of lemons" "lemon" is a title for an old car in USA, and later this term was used to call anything, in the quality level of which one could not be sure). One of G. Akerlof's conclusions deals with the fact, that business starting is not an easy task in low developed and developing countries [1].

In our study we propose to consider the role of information in innovation system development and information asymmetry issues. The main approach for information asymmetry in innovation system as "representing asymmetries of knowledge between the agents and the respective capabilities" is shown in [10], where information asymmetry is considered as one of major factors, influencing the risks taken to generate innovations.

Supporters of neo-classical theory considered information asymmetry as one of the main factors of market failure, but without this asymmetry in many cases novelty and variation of the product or processes is not possible (Hauknes, Nordgren, 1999) [3].

Schumpeter in study "Theory of Economic Development" [11] has considered search of such resource combination as the main entrepreneur function, which will provide possibility to obtain "new benefits" or use in new way already known effects.

Nancy T. Gallini and Brian D. Wright [7] suggested, that in technology transfer two problems play the most significant role: advantage of the licensor's pre-contractual information about economic value of information and the fact that the information exchange with licensor may assist in the technology inheriting (imitation).

However, in real conditions, i.e. in a situation where information in markets is imperfect and it is completely unknown for any of participants in market, its asymmetry is generated and consequently the absence of correlation between the economic system parameters.

Some authors point out, that it mostly concerns back transfer of technologies and knowledge. The research [6] creates theoretical base to study barriers for successful back knowledge transferring, including refusal from psychological contract, absence of the processing fairness is understood, absence of the internal motivation, psychic distance and responsibility of abroad.

Researching of patent market main peculiarities [4], which observe three factors, describes the market specifics: market safety, which forms participants' trust to the market information and makes all the participants to show true information about their products; market thickness, which is necessary for effective interconnection between seller and consumer; lack of congestion in market agreements.

Although there are numerous studies of information support and information asymmetry, the problem of country integration informational providing to global innovation system and high technologies international transfer from the viewpoint of innovation system resource support efficiency maximization, is not studied enough.

So the aim of this research is to analyze of informational asymmetry problems in the processes of innovation system security providing.

In methodological aspect of research we propose to consider technology as a resource of innovation system, which requires appropriate information support. Our suggestion is based on any hightech product understanding as a result of the different technologies application, that are used within the technological package, which was considered in our previous studies [8; 9; 14]. So we can move to understanding information as a factor of product development (to identify consumer needs), technology transfer (in technology search and selection), cooperation and therefore the security in different levels of innovation system.

Main material. Within this study we propose to understand innovation system as complex of 
multidisciplinary processes, which includes a number of different members with different competencies and capabilities, which constantly exchange knowledge and interact in order to produce new product, process or other innovations. That's why the effectiveness of innovation process is largely determined by the way, in which the main actors interact with each other as elements of collective system of knowledge creation and application (joint research and development, consulting, personnel training, purchasing of licenses, equipment etc.), as well as the technology used (technology transfer).

One of the main information support results are the data driven innovations. Data exploitation can create added value in variety of operations. First of all we can underline optimization of global value chains through the more efficient innovations use within the relationships with partners and customers. Nowadays the most relevant information about the demand for new kinds of products and new technologies can be obtained thought the information exchange between science, business, society and state (according to different innovation helix concepts).

In this context the innovation security threats we propose to consider as factors, that impede or in some cases even make impossible the realization of nation's interests and objectives in innovation field. According to our opinion the main information's function in this context also deals with the innovation activities coordination in complicated technological innovation systems development. Information on trends and prospects of development of science and technologies is necessary for strategic innovation planning.

Based on the information importance, information asymmetry as an unequal distribution of information between at least two stakeholders about the various parameters processes and events in the innovation system can cause development problems.

In the information asymmetry analysis innovation security we propose to consider in the mutual dependence of innovation system parameters and its degree of stability, which can be achieved through the information provision. But when we have no information support we can obtain innovation gaps. In some cases, national and sectoral innovation programs become mismatched and contradictory.

Information as an economic resource is used in a variety of ways, resulting in variety of forms and ways of value realization. Among the main areas should be distinguished:

- commercialization of information in products, services, technologies (creation of high-tech products, intelligent products, information services, development of new production and management technologies, etc.);

- effects on subjective perceptions and expectations of economic agents. As an examples we can name the creation of product's information image, company`s image (reputation), formation of needs or significant influence over them.

So in the case of very high degree of information asymmetry between the innovator and investor the market of innovation investment can simply disappear.

We can conclude, that information in innovation processes has triple nature:

1) information is necessary for all four renewable innovation process stages functioning. Different information is used to organize production thought the: technologies, standards and processes. While distinguishing it is necessary to have information about the agent, to whom goods and service will be provided;

2) information may have specific economic value, which is produced, distinguished, exchanged and consumed. In the process of information materialization new technologies are created, new goods, equipment and other non-material items are investigated;

3) information is uniting link between all stages of innovation processes. The effective renewable process is impossible without informational flows setting.

The more complex innovation is arranged in terms of available scientific and technical knowledge, the greater is the information asymmetry in the understanding of necessary resources for its 
development and its capabilities.

In the Fig. 1 the main aspects of information's role in innovation system development and the main activities for information asymmetry minimizing are shown.

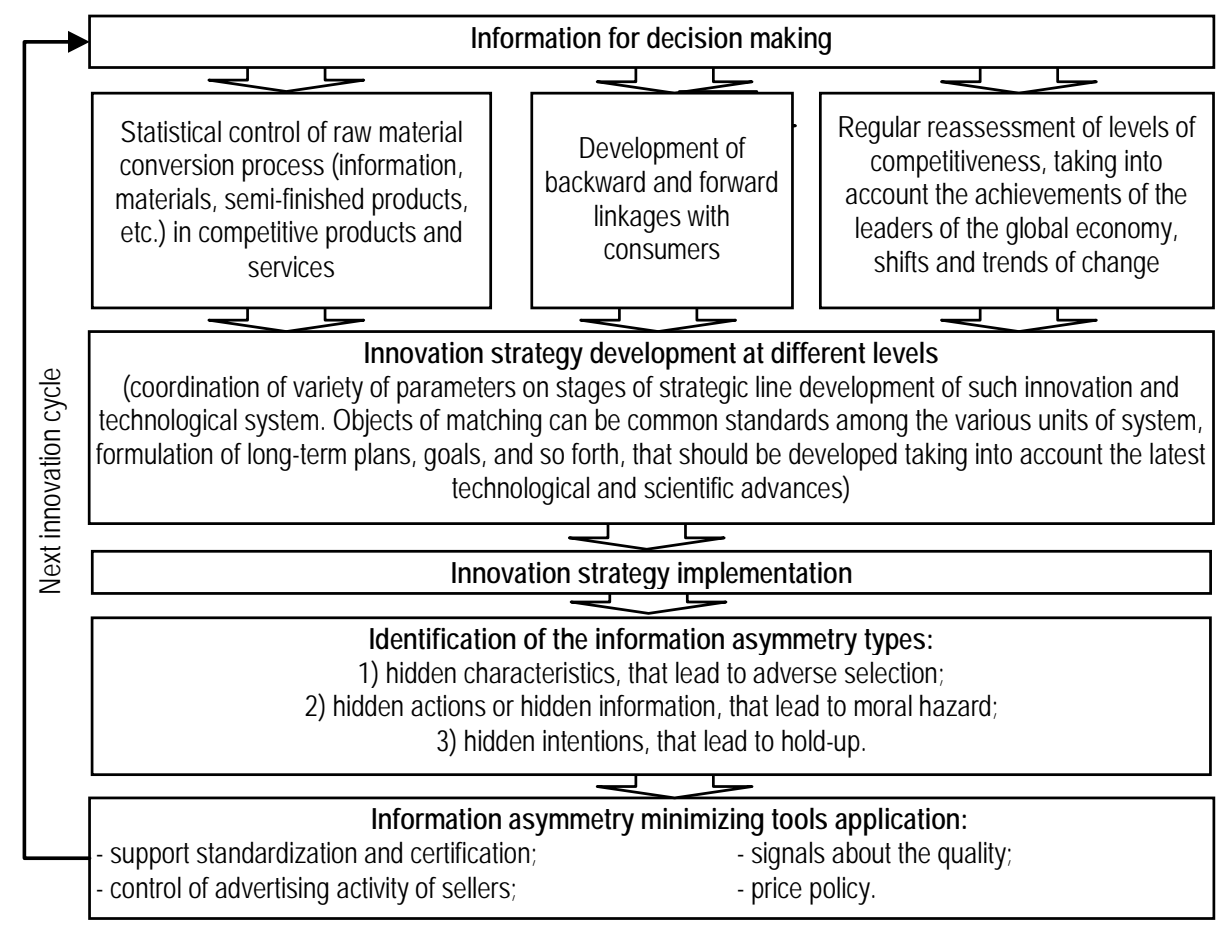

\section{Figure 1 - The role of information support and information asymmetry minimizing tools in innovation strategy (author`s approach)}

The informational security doctrine of Ukraine includes lagging of native knowledge-intensive and high technological productions to main threatens, uncontrolled expansion of modern informational technologies creates preconditions for Ukrainian technological dependence. The Doctrine of informational security in Russian Federation shows that purchase of import informational and telecommunication technologies with availability of domestic analogues causes threaten to informational and national security. In this case we also can note, that Geneva actions plan determines, that informational infrastructure is a necessary base for informational society.

This all corresponds to current economic and innovation trends: information is observed as one of the most significant resources in economic and innovation development together with availability material, energetic and human resources. To address these tasks we need to mentioned Paun F., who has paid a great attention to determination of concrete types of asymmetry in innovation process, including the risk asymmetry, cultural and institutional asymmetries and technological asymmetry, that are needed to be managed (reduced or compensated) in order to support efficient value creation through innovation system [10].

Information usually was a resource, however recently we have seen first attempts to perceive 
information including the context where economists observed substance and energy as resources. As a result one can see the informatization of economy - transformation of information into high-priority economic resource, based on computerization and telecommunications, providing principally new possibilities for economic development, frequent growth of the labor efficiency, solving of social and economic problems, establishment of the new economic relations type.

In case of economic situation state, the informational flow amount is increased (curve A on fig. 2). Information is stored, and achieving the management entities, it causes the necessity to correct economic structure of actions (curve S). Relevant reaction for external impacts increases the innovation activity efficiency (curve X). As soon as the process is stabilized (activity is corrected due to received information earlier, and new information is not taken into account), firstly, efficiency will be decreased, then information amount will be increased again (curve $A$ is risen).

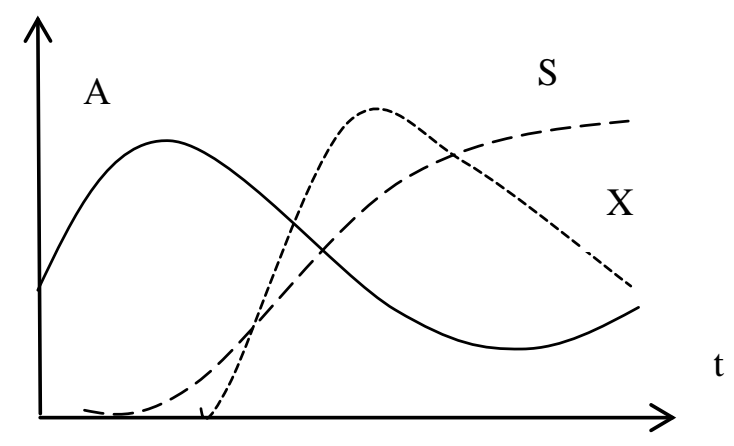

\section{Figure 2 - Dynamics of various resources and investment policy efficiency [15]}

Innovation development and technology transfer is a processes, that are depended on numerous factors: state support of innovative activity, the proper projects investments provision, state and perspectives of economy, political situation and state regular policy etc. Therefore, informational provision plays here the leading role.

Misbalance in international market of technologies is caused by competitive advantages in the country, which have great free resources to support informatization processes and to develop informational and communicative infrastructure. E.g., essential barrier for technologies transfer is a state of technological documents and informational resources, which have main information about technologies, data bases subdivision and fragmentary nature, lack of full technologies description, bad use of communication between participants of the innovative processes.

Our investigations and world experience proves, that under condition of weak expertise and state support inefficiency, there are additional motivations to create low-qualitative patents and innovations, that causes information asymmetry at technology market and reduces innovation activity and therefore an innovation system security. Therefore first of all number of effective researchers and innovators is important: the more there are researches and innovators at the market, the more there is the resource competition between them and probability, that state resource support will not lead to technologies quality decrease.

We also need to take into account the aspect, that getting information on innovation processes is associated with significant resource costs, so rational economic agent will not pay for information if the marginal cost of its obtaining will exceed the marginal revenue from its use. At the same information as commodity is characterized by clear representation of the optimal level of search costs. 
Effects of informational asymmetry and transaction expenses are defects of the economic entities' market interconnections microstructure, which cause problematic location of resources. Markets' functioning under conditions of information asymmetry has an influence on competitive processes efficiency. The existing mechanisms of information asymmetry effects smoothing can't prevent from market monopolization or from careless participants appearing.

So, we come to the necessity of state interference and to develop the proper informational and economic mechanism, oriented, to reduce negative consequences of the information asymmetry. In 2001 J. Stieglitz, G. Akerlof and M. Spence were awarded with Nobel Prize for explanation of informational markets functioning and information misrepresentation, appeared at the markets, and lead to state regulation necessity.

Analysis of seven open innovations examples [2] shows that interorganizational relations, assisting the open innovations, can be classified depending on their indirect or direct impact and exchange of intellectual property or innovation abilities. The reasonability of market relations or IP source mediators and / or innovative potential depends on informational asymmetry and possible decisions, workability of the innovations potential partners (decisions makers), and also process to buy foreign innovations (including the problem of specification, decisions estimation, transfer etc).

For example, undetermined percentage of intellectual activity patented results practical use is preconditioned by the following circumstances, which complicate the innovations transfer conduct:

1. Low level of infrastructural provision system development to manage on innovation development, risk base, with purpose to receive necessary level of entrepreneurial income;

2. The informational asymmetry of knowledge-intensive technologies and innovations market is observed;

3. There is no necessary diversification of proposed service by the market in the sphere of innovations transfer;

4. Low developed functional labour specialization in sphere of innovations development and technology transfer;

5. There are no legal and well determined rights for intellectual property in high technological spheres.

The mentioned above problems appear owing to linear approach to the innovative process, which was particular for pre-innovative age (till 70 s of $X X$ century), that now is changed by innovative processes non-linearity.

The third generation of the innovative process (the beginning of 1970s, mid 1980s) is a coupling model, which focuses on connection of technological abilities and possibilities with market demands. According to this model, innovative idea may be generated at any stage of the cycle, more often as a result of the marketing analysis. After that usually the necessary scientific or engineering knowledge for idea realization is searched. If such knowledge exists (e.g. patent), then it will be achieved and included into the innovative cycle as the final element. In other case target research is carried out nowadays in order to keep competitiveness, adaptation to fifth generation of the innovative process is required: strategic networking model, which consists in strategic integration and ties establishment - new functions are added to the parallel process using information technologies.

In this situation cooperation is most common type of assistance systems, characterized by the need to unite their specific properties

The most important criterion of innovation development success is its informational and marketing provision, which is characterized by network character [5]. Network data let to provide contacts with purpose to find partners and purchasers. Thus, at this time leaders of the companies actively start to reinterpret the role and value of communications and communicative technologies. Cooperation in innovation networks is characterized by high degree of openness and symmetric dependence of 
partners and is focused on common solutions offering.

However, information asymmetry can lead to problem moments in innovation cooperation. For example, in «linking model», that is designated unsymmetrical cooperation between the two countries, when the foreign partners were involved in implementation of projects on the use and exploration of outer space, which were developed and managed by the leading countries, particularly the United States. It does not protect the integrity (independence level) of national innovation systems and projects. Allocated problem is part of North-South problem, but it also contains potential threats for vide range subjects of strategic partnerships.

Also, innovation policy is expressed in the creation of clusters as an association of enterprises and competitive industries. The essence of cluster is the mutual support of all businesses and industries in cluster. Within it information is sent very quickly, and the participants have the great advantages that are associated with constant access to new methods, technologies, etc.

Information asymmetry is caused also by information shock: approximately $30 \%$ of scientific publications are multinational scientists' groups' results for today and $7 \%$ of patents were received owing to the researching corporation [13].

OECD specialists' suppose, that the main factors, influencing the degree of national science internationalization, are: country scales, technological provision, geographic closeness to regions with high scientific and research activity, language factor, branch specialization, foreign companies location in the state etc. High degree of internationalization is particular for small European countries, where the native research potential is limited. On the example of EU we can observe the excellent system of information support and innovation activities coordination.

On the basis of it, informational provision takes leading position in strategic decision solving about new technologies transfer. It is possible to delay this process in case of uncertainty, however in this case risk to lose competitive advantages is increasing. Due to several estimations, $90 \%$ were received for the last 30 years [12] of all knowledge scope, presented in physical units, which society has.

As a result of the information asymmetry about intellectual assets at the patent market new business types have been formed. They are based on using of the patent system incompleteness, time advantages and careless use of knowledge and experience to held agreements with patents and use specific methods to run business. It allows to relate them to new specific variety of financial mediators (Patent Aggregators).

Unlike companies, which produce or sell products, non-practicing organization can't be given symmetric counter action, because they do not produce goods or service. Patent system has to protect producers' interests; however non-practicing organizations can use its disadvantages in their interests and get benefit, not available for producing companies.

Very often for subject who carry out technological transfer under conditions of misunderstanding situation at the market, change of traditional production forms into new technologies often leads to bankruptcy in business, because it may be turned out while entering the market that:

- analogue has already existed; it is the accurate copy of supply and it has already taken some niche at the market, that would complicate or prohibit successful continuance of the commercial activity;

- use of suggested innovation results in commercial aims is banned, because there is an analogue, protected by law.

To overcome the information vacuum in US and UK, the companies, traded on a stock exchange, are required to publish data about their level of R\&D expenditures as an indicator of innovation activity that is understandable for potential investors.

In case of technology transfer, we suggest to distinguish two equal informedness concerning technologies market: internal (searching of technology within economic entity locating-country) and 
external, and to observe them in the view of technology transfer process resources. In the case of potential technology absence at the national market the subject has to observe international segment at the target market. Therefore poor perspectivity risk of technological innovation has to be analyzed as a result of its use in different national innovation systems (or within the different technological packages (systems) as an environment of technology application).

Analyzing the realization of the state innovative policy, one can point out its essential dependence on informational asymmetry prevention between small innovative enterprises and potential investors, because most processes are innovative and investment in the high technologies sphere. In order to increase market informedness and innovative risks reducing, developed countries actively assist cooperation between investors and entrepreneurs, support formation of credit histories bureau, provide small companies with consulting service on business-plans and financial projects preparation, provide small innovative enterprises to come to an international level.

Our previous studies confirm the reasonability to form entrepreneurial structures in knowledgeintensive technologies and innovations transfer sphere. In the high technological spheres mediating structures let to provide non-price factors, through which information price is defined, particularly risk level, novelty, probability and fullness, timeliness, confidentiality (presence or absence of copies), unlike most physical goods and service.

Conclusion and further research directions. In the article we have shown, that the innovation system resources security is impossible without efficient information support, i.e. monitoring of domestic and foreign markets interests in investigations and also without marketing research of high technologies global markets.

Information contains reserves of productivity increasing and other resources using optimization. Success in resource support activities cannot be conducted without orientation to the technologies modern classification, performed not only by their sector belonging, but by the analyzing of information concerning numerous other dimensions of its application.

Based on understanding that today innovations are unlimited, that's why they are «open» or «collaborative» («co-innovations»), we have considered an information asymmetry as serious problem of national innovation system. In the international scale we can see the models of asymmetric cooperation, that were caused by information asymmetry.

More and more countries conclude that globalization is not a threat, but an opportunity. Life cycle shortening of technological decisions, convergence, inter-branch integration and globalization are main tendencies of the high technologies development at the modern stage. Therefore informational provision role is greatly increased, efficiency of which lets to become strong player in the global innovation space. Information in multidimensional system of economic interdependencies and interactions, based on a complex combination of mechanisms of competition, cooperation and partnership at the macro and micro levels, interweaving the emerging global market and the continuing national and local markets.

In further studies its necessary to develop methodology of identification the degree of information asymmetry in development of technological packages in order to maximize its efficiency.

1. Akerlof G. The Market of Lemons: Quality Uncertainty and the Market Mechanism / G. Akerlof // Quarterly Journal of Economics. - 1970. - № 84. - P. 488-500.

2. Feller J. Institutionalising Information Asymmetry: Governance Structures for Open Innovation / J. Feller, P. Finnegan, J. Hayes, P. O'Reilly I/ Information Technology \& People. - 2009. - Vol. 22, No. 4. - pp. 297-316.

3. Hauknes J. Economic Rationales of Government Involvement in Innovation and the Supply of Innovation-related Service I J. Hauknes, L. Nordgren // STEP Report series. - 1999. - № 199908.

4. Gans J.S. Is there a market for ideas? / J.S. Gans, S. Stern // Industrial and Corporate Change. - 2010. - № 19(3). P. 805-837. 
5. Krapyvny I.V. International innovation networks as new stage of innovation development [Електронний ресурс] / I.V. Krapyvny, V.A. Omelyanenko, N.O. Vernydub // Economic Processes Management. - 2015. - № 1. - Режим доступу : http://epm.fem.sumdu.edu.ua/download/2015_1/2015_1_17.pdf.

6. Millar $C$. Reverse knowledge and technology transfer: imbalances caused by cognitive barriers in asymmetric relationships / C. Millar, J. Choi Ch // International Journal of Technology Management. - 2009 . № 48 (3). - P. 389-402.

7. Nancy T. Gallini Wright Technology Transfer under Asymmetric Information / T. Gallini Nancy, D. Brian // RAND Journal of Economics, The RAND Corporation. - 1990. - Vol. 21 (1). - P. 147-160.

8. Omelyanenko V.A. Analysis of Potential of International Inter-Cluster Cooperation in High-Tech Industries // International Journal of Econometrics and Financial Management. - 2014. - Vol. 2, No 4. - P. 141-147.

9. Omelyanenko V.A. General context of economic and legal reforms international comparative studies (example of innovation development) [Електронний ресурс] / V.A. Omelyanenko // Economic Processes Management. - 2016. - № 3. - Режим доступу : http://epm.fem.sumdu.edu.ua/download/2016_3/epm2016_3_8.pdf.

10. Paun F. Asymmetries and dynamic interactive capabilities in technology transfer between ONERA - the French Aerospace LabTM and SMEs / F. Paun, N. Von Tunzelmann, P. Richard // Journal of Innovation Economics \& Management. 2012. - № 1. - P. 103-137.

11. Schumpeter J. The Theory of Economic Development/ J. Schumpeter. - Cambridge: Harvard University Press, 1934.

12. Ленчук Е.Б. Технологическая квазирента [Електронний ресурс] / Е.Б. Ленчук // Независимая газета. 23.05.2007. - Режим доступу : http://www.ng.ru/science/2007-05-23/13_kvazirenta.html.

13. Мельникова Т. Тенденции международной исследовательской кооперации [Електронний ресурс] / Т. Мельникова // Промышленная собственность. - 2012. - Режим доступу : http://www.innovprom.ru/tendenciimezhdunarodnoj-issledovatelskoj-kooperacii.

14. Омельяненко В.А. Науково-методичний підхід до аналітичного забезпечення проектів розвитку технологічних систем / В.А. Омельяненко // Управління проектами та розвиток виробництва. - 2016. - № 2(58). - С. 18-26.

15. Сухарев О.С. Экономика технологического развития / О.С. Сухарев. - М. : Финансы и статистика, 2008 - 481 с.

1. Akerlof, G. (1970). The Market of Lemons: Quality Uncertainty and the Market Mechanism. Quarterly Journal of Economics, $84,488-500$.

2. Feller, J., Finnegan, P., Hayes, J. \& O'Reilly, P. (2009), Institutionalising Information Asymmetry: Governance Structures for Open Innovation. Information Technology \& People, 22(4), 297-316.

3. Hauknes, J., \& Nordgren, L. (1999). Economic Rationales of Government Involvement in Innovation and the Supply of Innovation-related Service. STEP Report series, 199908.

4. Gans, J.S., \& Stern, S. (2010), Is there a market for ideas? Industrial and Corporate Change, 19(3), 805-837.

5. Krapyvny, I.V., Omelyanenko, V.A., \& Vernydub, N.O. (2015). International innovation networks as new stage of innovation development. Economic Processes Management, 1. Retrieved from http://epm.fem.sumdu.edu.ua/download/2015_1/2015 1_17.pdf.

6. Millar, C., \& Choi, Ch. J. (2009), Reverse knowledge and technology transfer: imbalances caused by cognitive barriers in asymmetric relationships. International Journal of Technology Management, 48(3), 389-402.

7. Nancy, T. Gallini, \& Brian, D. Wright (1990), Technology Transfer under Asymmetric Information. RAND Journal of Economics, The RAND Corporation, 21(1), 147-160.

8. Omelyanenko, V.A. (2014). Analysis of Potential of International Inter-Cluster Cooperation in High-Tech Industries. International Journal of Econometrics and Financial Management, 2(4), 141-147.

9. Omelyanenko, V.A. (2016). General context of economic and legal reforms international comparative studies (example of innovation development). Economic Processes Management, 3. Retrieved from http:/lepm.fem.sumdu.edu.ua/download 12016_3/epm2016_3_8.pdf.

10. Paun, F., Von Tunzelmann, N., \& Richard, P. (2012). Asymmetries and dynamic interactive capabilities in technology transfer between ONERA - the French Aerospace LabTM and SMEs. Journal of Innovation Economics \& Management, 1, 103-137.

11. Schumpeter, J. (1934). The Theory of Economic Development. Cambridge: Harvard University Press.

12. Lenchuk, E.B. (2007). Tehnolohicheskaia kvazirenta [Technology quasi rent]. Nezavisimaia hazeta - Independent digest. Retrieved from http://www.ng.ru/science/2007-05-23/13_kvazirenta.html [in Russian].

13. Melnikova, T. (2012). Tendencii mezhdunarodnoi issledovatelskoi kooperatsii [Trends in international research cooperation]. Promyshlennaia sobstvennost - Industrial property. Retrieved from http://www.innovprom.ru/tendenciimezhdunarodnoj-issledovatelskoj-kooperacii [in Russian].

14. Omelyanenko, V.A. (2016). Naukovo-metodichniy pidhid do analitichnoho zabezpechennia proektiv rozvitku tehnolohichnykh system [Scientific and methodical approach to analytical support of technological systems development projects]. Upravlinnia proektamy ta rozvytok vyrobnytstva - Project management and development of production, 2(58), 18-26 [in Ukrainian].

15. Sukharev, O.S. (2008). Ekonomika tehnolohicheskoho razvitiia [Technological development economics]. Moscow: Finance and Statistics [in Russian]. 


\section{В.А. Омельяненко. Аналіз інформаційної асиметрії в контексті забезпечення безпеки інноваційної системи}

B.A. Омельяненко, канд. екон. наук, старший науковий співробітник, Сумський державний педагогічний університет ім. А. С. Макаренка (м. Суми, Україна)

Аналіз інформаційної асиметрії в контексті забезпечення безпеки інноваційної системи

у статті розглянуто основні аспекти ролі інфоормації у розвитку інноваційної системи. Запропоновано розелядати роль інформації в контексті забезпечення інноваційної безпеки та ресурсної безпеки інноваційної системи. Визначено основні форми прояву інфоормаційної асиметрії та її наслідки для різних інноваційних агентів. У рамках аналізу інформаційної асиметрії інноваційну безпеку запропоновано розелядати у взаємній залежності параметрів інноваційної системи та ступеня ії стійкості, що може бути забезпечене через інформаційне забезпечення. На основі аналізу світового досвіду запропоновано заходи для зниження інформаційної асиметрії.

Ключові слова: інноваційна система, інноваційна безпека, інформаційна асиметрія, стратегія, трансфрер технологій, ринок.

B.A. Омельяненко, канд. экон. наук, старший научный сотрудник, Сумский государственный педагогический университет им. А. С. Макаренко (г. Сумы, Украина)

Анализ информационной асимметрии в контексте обеспечения безопасности инновационной системь

В статье рассмотрены основные аспекты роли информации в развитии инновационной системы. Предложено рассматривать роль инфрормации в контексте обеспечения инновационной безопасности и ресурсной безопасности инновационной системы. Определены основные формы проявления информационной асимметрии и ее последствия для разных инновационных агентов. В рамках анализа информационной асимметрии инновационную безопасность предложено рассматривать во взаимной зависимости параметров инновационной системы и степени ее стойкости, что может быть обеспечены через информационное обеспечение. На основе анализа мировой опыт предложен мерь по снижению информационной асимметрии.

Ключевые слова: инновационная система, инновационная безопасность, информационная асимметрия, стратегия, трансфрер технологий, рынок.

Отримано 15.11.2017 p 